\title{
ÚJ LEHETŐSÉGEK A KUKORICA (ZEA MAYS L.) ÖNTÖZÉSÉBEN
}

\author{
Futó Zoltán - Bencze Gábor
}

\begin{abstract}
Absztrakt: A hazai kukoricatermesztés eredményei a világon tapasztalt hozam és termésmennyiség növekedéstől jelentősen elmaradnak. Hazánkban a kukorica terméslimitáló tényezője a jó vízellátás. A kukorica termésátlaga jelentősen növelhető, ha javítjuk a növény vízellátását. Sok területen csak igen kevés víz áll rendelkezésre a szakszerü öntözéshez. Kísérletünkben csepegtetöszalagos öntözés hatását vizsgáltuk a kukorica termésátlagára. A kísérletet Szarvason, a Szent István Egyetem Agrárés Gazdaságtudományi Kar, Iskolaföldi kísérleti területén állítottuk be. Vizsgálataink alapján a hozamok 22,3-24,5\%-kal növekedtek a kontroll, öntözetlen parcellák eredményeihez képest, mely a vizsgált években a termésátlag növekedése szempontjából már ökonómiailag is gazdaságos volt.
\end{abstract}

Abstract: The results of Hungarian maize production are significantly below the yields and total quantity in the world. Maize yields can be increased significantly if we improve the plant's water supply. The yield of maize can be significantly increased by improving the water supply of the plant. In many areas, only little water is available for irrigation. The effect of drip irrigation in our experiment was examined for the yield of corn. The experiment was set up at Szarvas in the experimental field of the University of Szent István, Faculty of Agricultural and Economics Studies, in Iskolaföld. The yields increased by $22.3-24.5 \%$ compared to the yields of control plots. In our experiment, the growth of the average yield was good for economically.

Kulcsszavak: kukorica, öntözés, csepegtetö öntözés, termésátlag,

Keywords: maize, irrigation, drip irrigation, yield,

\section{Bevezetés}

A világ egyre növekvő népessége igen jelentős kihívás elé állítja a világ mezőgazdasági termelését. A jelenlegi ismereteink szerint a következő 50 év alatt a Föld lakossága jelentősen növekedik és meghaladja majd a 9-10 milliárd föt. A növekvő népesség igen jelentös élelmiszer termelést követel meg, ezért az előállított kukorica mennyiségét is növelni szükséges.

$A z$ utóbbi években a rizs vetésteruiletét megelőzve, a búza után a legnagyobb területen termesztett szántóföldi növény a kukorica. Az egész világon való elterjedését jó alkalmazkodóképességének köszönheti. FAO adatok alapján az összes termés mennyisége 2013-ban már meghaladta az 1,0 milliárd tonnát. A világ termőterületének 5,3\%-át és a termelés 6,5\%-át az EU tagállamok teszik ki, Magyarország részesedése $0,7 \%$ körül alakul.

A kukorica Magyarországon föként, mint energiadús állati takarmány jön számításba. Az állatok takarmányozásában elsősorban energiaszállító szerepe jelentős. Keményítötartalma nagyon magas $65-70 \%$, energiaértéke $8,5-9,5 \mathrm{MJ} / \mathrm{kg}$ szárazanyag. A Magyarországon megtermelt kukorica 89,5\%-át takarmányozási célra használják fel.

\section{Irodalmi áttekintés}

A kukorica vízigénye közepes, $450-550 \mathrm{~mm}$. Napi vízfogyasztása ennek megfelelően 4,5-5,5 mm/ha (45-55 $\left.\mathrm{m}^{3} / \mathrm{ha}\right)$. Meg kell különböztetnünk az abszolút 
vízfogyasztáson túl statikai vízigényt is. A kukorica statikai vízigénye azt jelenti, hogy talaj pórustérfogatának hány \%-át tölti ki víz és hány \%-át levegő; (kukorica statikai vízigénye: $67-79 \%$ ). A kukorica transzspirációs együtthatója azt jelenti, hogy egységnyi szárazanyag (pl. $1 \mathrm{~kg}$ ) előállításához mekkora a felhasznált víz mennyisége (kukorica kb. 350 l/kg). (Bocz, 1992)

A kukorica vízigényét, és vízfelvételét jellemző egyéb tényezők:

- A kukorica 150-200 cm mélységből is képes felvenni a vizet.

- A címerhányás időszaka alatti aszály 53\%-kal, a szemtelítődés alatti aszály 30\%-kal csökkenti a termést.

- Az elérhető maximális termést nem csak a tenyészidőben lehullott csapadék, hanem az őszi-téli félév csapadék mennyisége is befolyásolja.

- Elöfordulhat, hogy nem a csapadékos évben kiemelkedőek a kukoricatermések, hanem az azt követö évben, amikor a hőmérséklet is kedvező. A talajok akár $500 \mathrm{~mm}$ vizet is tudnak tárolni (200 cm mélységig), melynek 50\%-a diszponibilis víz.

- A túl sok csapadék is káros lehet a kukorica szempontjából, mivel a pórustérfogat vízzel telítődése miatt a gyökerek oxigénellátása nem megfelelő (Pepó-Sárvári, 2011).

A vízigény a tenyészidő folyamán változik. Legtöbb vizet vesz fel a kukorica a címerhányástól a szemtelítődésig tartó időszakban. Ilyenkor a napi vízigénye 4,5-5,5 mm között van, az összegzett vízigény pedig eléri a 200-250 mm-t. (Csajbók, 2004)

A kukorica vízfogyasztásának üteme és növekedési tendenciája - a klasszikus megállapításoknak megfelelően - a növényfejlődés ütemével párhuzamosan a növekvő vegetatív tömeggel párhuzamos. A fejlődés kezdetén és a szemtelítődés utáni időszakban kisebb a növények vízfogyasztása. Legtöbb vizet a kukorica a címerhányástól a szemtelítődésig terjedő időszakban igényli (Antal et al., 2005).

\section{1. ábra: Az öntözött területek változása a világon}

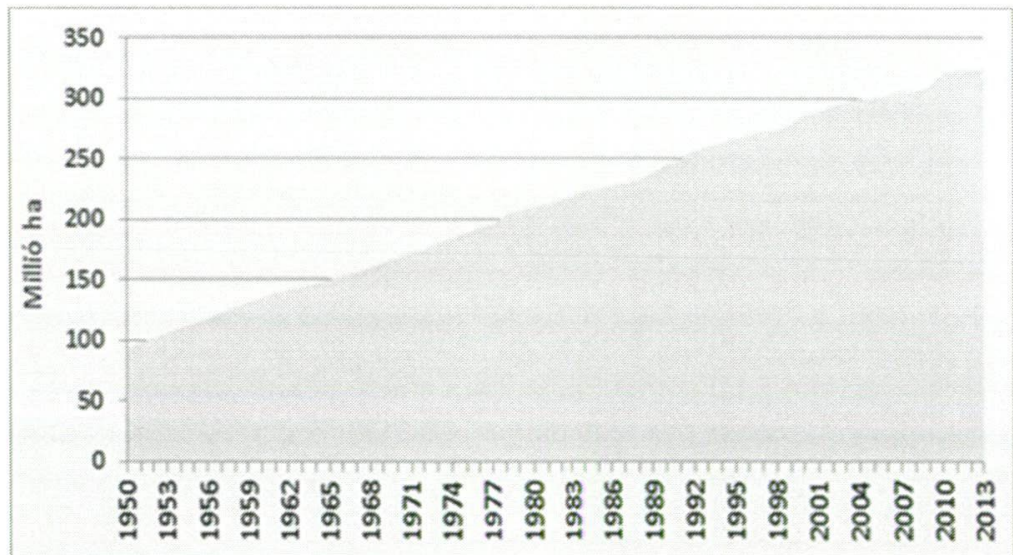

Forrás: FAO.org (2013) 
A kukorica termésátlagának növelésére hazánkban leggyorsabban az öntözés fejlesztésével tudunk reagálni. A kukorica öntözési reakciója kiváló, az öntözés okozta terméstöbblet, évjárattól és a csapadék mennyiségétől függöen $10-90 \%$ is lehet. A világon a mezőgazdasági öntözött területek aránya folyamatosan növekszik 2013-ban már meghaladta a 325 millió hektárt, amely jelentősen hozzájárul a termésátlagok növekedéséhez a világon. (lásd: 1 . ábra)

A kukorica a gyökereivel mély talajréteget $(200-250 \mathrm{~cm})$ szö át, így a talajban tárolt nedvességböl sokat vesz fel. A felvett vizet - szélsőségesen rossz körülményeket leszámítva - jól hasznosítja. A vízigényének csúcsidőszaka miután július, augusztus hónapra esik és más növényeinkhez viszonyítva hosszú, ezért a kukorica aszályérzékenysége nagy. (Szalóki, 1989)

A kukorica öntözési reakciója elég jó. Az öntözés hatására várható terméstöbblet az évjárattól és genotípustól függően 2-6 t/ha. Az $1 \mathrm{~mm}$ öntözővízre jutó terméstöbblet $20-40 \mathrm{~kg}$ is lehet. Csak a jó öntözési reakciójú, nagy termőképességü hibridek öntözhetők sikeresen, a hibridek között lényeges különbségek vannak. (Csajbók, 2004; Ruzsányi, 1981)

\section{Anyag és módszer}

2016-ban és 2017-ben Szarvason vizsgáltuk a szalagos csepegtető öntözés hatását a kukorica termésátlagának és termésképző elemeinek változására. A vizsgálatban a Metra Kft. által forgalmazott Aqua Traxx szalagos csepegtető rendszert használtuk. A kísérlet során alkalmaztunk öntözés nélküli (kontroll) parcellákat, a kukorica vízigényét $75 \%$-ban és $100 \%$-ban kielégítő szalagos csepegtető öntözésben részesített parcellákat, illetve a $100 \%$-os vízigényt kielégítő öntözést kiegészítettük komplex vízoldható (NPK) mütrágyával, amely alkotta a vizsgálat negyedik kezelését. 2017-ben vízoldható mütrágya helyett egy huminsav kezelést alkalmaztunk. A kísérletben egy vezető Pioneer hibridet, egy vezető Monsanto hibridet és egy Martonvásári nemesítésü csemegekukorica hibridet vizsgáltunk.

A kísérlet talajára jellemző, hogy a fizikai félesége agyagos vályog, kémhatása savanyú, illetve gyengén savanyú, a müvelt réteg $\mathrm{CaCO}_{3}$-ot nem tartalmaz, a humusztartalom alapján a talaj $\mathrm{N}$ - szolgáltatása közepes. A talaj vízgazdálkodását a gyenge vízvezető képesség és a nagy víztartó képesség jellemzi. A müvelt szint tömődött, összporozitása, és ezen belül a gravitációs pórusok aránya kisebb.

$\mathrm{Az}$ öntözés hatását minden esetben jelentősen befolyásolja az adott évjárat vízellátása, a lehullott csapadék mennyisége. 2016. év igen kedvező volt Szarvas térségében. A lehullott csapadék mind mennyiségét, mind pedig időbeli eloszlását tekintve igen kedvező volt a kukorica számára. (lásd: 1. táblázat) 
1. táblázat: Időjárási adatok a 2016. január - október, Szarvas, 2016-2017.

\begin{tabular}{|l|c|c|c|c|c|c|c|c|c|c|c|}
\hline hónap (1) & jan. & feb. & márc. & ápr. & máj. & jún. & júl. & aug. & szept. & okt. & $\begin{array}{l}\text { összeg/ } \\
\text { átlag (6) }\end{array}$ \\
\hline $\begin{array}{l}\text { Hömérséklet } \\
\text { ('C) (2) }\end{array}$ & $-0,9$ & 6,0 & 7,3 & 13,4 & 16,6 & 21,3 & 22,5 & 21,1 & 18,3 & 10,4 & 12,1 \\
\hline $\begin{array}{l}\text { Csapadék (mm) } \\
\text { 2016 (3) }\end{array}$ & 61,6 & 88,5 & 20,0 & 12,3 & 18,8 & 124,4 & 124,4 & 50,5 & 9,8 & 68,4 & 578,7 \\
\hline $\begin{array}{l}\text { Csapadék (mm) } \\
\text { 2017 (7) }\end{array}$ & 28,3 & 30,2 & 13,4 & 49,7 & 40,9 & 69,3 & 31,8 & 33,3 & 56,1 & 56,2 & 408,8 \\
\hline $\begin{array}{l}\text { 30 éves csapadék } \\
\text { (mm) (4) }\end{array}$ & 30,6 & 32,4 & 30,9 & 43,9 & 58,9 & 68,4 & 51,4 & 52,4 & 39,8 & 43,6 & 452,3 \\
\hline $\begin{array}{l}\text { Eltérés 2016. } \\
\text { (mm) (5) }\end{array}$ & 31,0 & 56,1 & $-10,9$ & $-31,6$ & $-40,1$ & $\mathbf{5 6 , 0}$ & $\mathbf{7 3}$ & $-1,9$ & $-30,0$ & 24,8 & 126,4 \\
\hline $\begin{array}{l}\text { Eltérés 2017. } \\
\text { (mm) (8) }\end{array}$ & $-2,7$ & $-2,2$ & $-17,5$ & 5,8 & $-18,0$ & 0,9 & $\mathbf{- 1 9 , 6}$ & $\mathbf{- 1 9 , 1}$ & 16,3 & 12,6 & $-43,5$ \\
\hline
\end{tabular}

Forrás: A szerző saját szerkesztése.

2017. évben a tenyészidő szinte teljes egészében kevesebb csapadék hullott, mint a sokévi átlag, amelynek köszönhetően a kukorica a legérzékenyebb, virágzás körüli fejlettségét már jelentős vízhiánnyal tudta csak megkezdeni. A július, augusztus hónapok csapadékhiánya tovább rontotta a kukorica terméspotenciálját, amelynek eredményeként elmondható, hogy a 2017. év a növény számára csak jó-közepes klimatikus viszonyokat teremtett.

A növények fejlödését és a termésátlag kialakítását döntöen befolyásolja a növény fotoszintetikus aktivitása. A fotoszintézis két fontos tényezőtől függ legeröteljesebben 1. a növény felületének és tartósságának nagysága, 2. a levél fotoszintetikusan aktív klorofill tartalma. A kísérletben ezért mértük a növény relatív klorofill tartalmát, amely megmutatja, hogy a levél fotoszintetikus aktivitását mekkora mértékben képes befolyásolni az öntözés és az öntözővízzel együtt kijuttatott folyamatos tápanyagellátás (tápoldatozott kezelés). A relatív klorofill tartalmat Konica Minolta SPAD 501 mérőműszerrel mértük.

A kukorica vízigényének $75 \%$-os és $100 \%$-os kielégítését a kísérleti terület átlaghőmérsékletének és az állomány evapotranszspirációjának ismeretében végeztük. A $100 \%$-os parcellák vízigényét az evapotranszspiráció ismeretében teljesen pótoltuk, a terület $85-100 \%$ körüli természetes vízkapacitással rendelkezett. A 75\%-os vízigényt kielégítỏ kezelésben az evapotranszspiráció ismeretében az elpárologtatott vízmennyiségnek csak a 3/4-ét juttattuk ki alkalmanként, amely egy folyamatosan csökkenó vízkészletet eredményezett. A parcellák természetes vízkapacitása 45-80\% között változott. A kontroll parcellák nem kaptak semmilyen öntözést, a természetes csapadék határozta meg a terület természetes vízkapacitását. Mivel az év csapadékellátottsága kedvezően alakult, a parcellák vízkapacitása hasonló volt a kontroll parcellákéhoz, 40-75\% között változott.

\section{Eredmények és értékelésük}

Az eredményeknél látható, hogy a vízellátás csak a $100 \%$-os vízigénynél növelte a kukorica relatív klorofill tartalmát. A $75 \%$-os vízellátás az idei évben nem 
különbözött jelentősen a kontroll öntözés nélküli parcellák eredményeitől, a kiváló csapadék eloszlásnak köszönhetően. (lásd: 2. táblázat).

\section{2. táblázat: A kukorica relatív klorofill tartalma 2016-2017. (SPAD érték)}

\begin{tabular}{|c|c|c|c|c|}
\hline & $\begin{array}{c}\text { Kontroll } \\
\text { (1) }\end{array}$ & $\begin{array}{c}75 \% \text {-os vízigényü } \\
\text { öntözés (2) }\end{array}$ & $\begin{array}{c}100 \% \text {-os vízigényü } \\
\text { öntözés (3) }\end{array}$ & $\begin{array}{c}100 \% \text {-os vízigény + } \\
\text { tápoldat }(4)\end{array}$ \\
\hline Csemegekukorica & 41,7 & 41,6 & 46,1 & 46,6 \\
\hline P9903 hibrid & 43,2 & 43,5 & 46,7 & 46,8 \\
\hline DKC4541 hibrid & 43,0 & 43,6 & 46,6 & 46,8 \\
\hline Átlag 2016 (5) & 42,63 & 42,90 & 46,46 & 46,73 \\
\hline P9903 hibrid & 44,1 & 43,7 & 45,9 & 46,4 \\
\hline DKC4541 hibrid & 43,2 & 43,9 & 45,8 & 46,7 \\
\hline Átlag 2017 (5) & 42,80 & 43,17 & 45,67 & 46,33 \\
\hline
\end{tabular}

Forrás: A szerző saját szerkesztése. (2017.)

Elsőként a csemegekukorica termésátlagát vetettük vizsgálatunk alá, amely csak a 2016. évi vizsgálatban szerepelt. A termésátlagok mérése során az öntözés nélküli (kontroll), a 75\%-os vízigényig öntözött, a kukorica 100\%-os vízigényéig öntözött és az öntözéssel együtt tápoldatot is kapó parcellák terméseredményeit hasonlítottuk össze. A csemegekukorica hozamait a gyakorlatnak megfelelő magasabb ( 60-70\%os) nedvességtartalomnál, és csöves betakarítási súllyal fejeztük ki.

\section{2. ábra: A csemegekukorica termésátlagának alakulása szalagos csepegtető öntözéses kísérletben 2016. (Szarvas)}

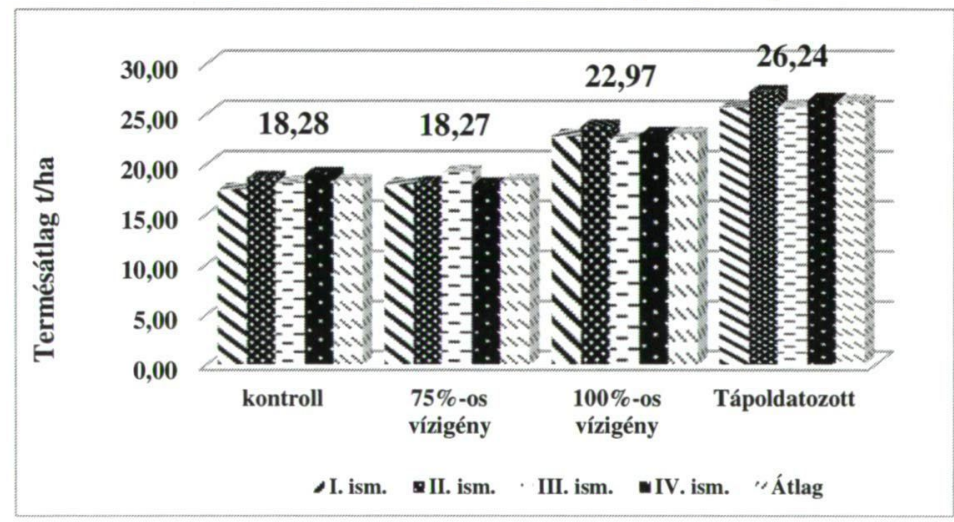

Forrás: A szerző saját szerkesztése. (2016.)

Az eredményekből látható, hogy a csemegekukorica termésátlagait az igen kedvező 2016-os évben is jelentősen lehetett növelni a szalagos csepegtető öntözési technológia alkalmazásával. A kedvező csapadék-ellátottság miatt a kísérletben nem volt különbség az öntözés nélküli (kontroll) és a 75\%-os vízigényt kielégítő öntözés parcelláinak termésátlaga között. A növény teljes vízigényét kielégítő öntözés termésnövelő hatása azonban igen jelentős volt még ebben a kedvező vízellátottságú évben is. A csemegekukorica termésátlaga elérte a 22,97 t/ha értéket, amely igen 
kedvező. Ezt a hozamot a kísérletben csak a tápoldatozott parcellák terméseredményei múlták fölül, a hozam elérte a 26,24 t/ha-t.

3. táblázat: A csemegekukorica termésátlagának variancia táblázata

\begin{tabular}{|l|c|c|c|c|c|}
\hline & SQ & df & MS & F & Sig. \\
\hline Corrected Model & $181,788^{\mathrm{a}}$ & 3 & 60,596 & 145,718 &, 000 \\
Intercept & 6449,958 & 1 & 6449,958 & 15510,454 &, 000 \\
Öntözés & 58,844 & 2 & 29,422 & 70,752 & $\mathbf{, 0 0 0}$ \\
Tápoldat & 21,386 & 1 & 21,386 & 51,427 & $\mathbf{, 0 0 0}$ \\
Error & 4,990 & 12 &, 416 & & \\
Total & 7540,698 & 16 & & & \\
Corrected Total & 186,778 & 15 & & & \\
\hline
\end{tabular}

a. R Squared $=, 973$

A statisztikai vizsgálat során bebizonyítottuk, hogy a csepegtető szalagos öntözés még egy kedvező vízellátású évjáratban is statisztikailag igazolható módon tudta növelni az elérhető termésátlagokat csemegekukorica termesztés esetén. Hasonló megállapítást tehettünk a tápoldat hatásának vizsgálatakor, a szalagos csepegtető öntözéssel kijuttatott tápanyag tovább növelte a csemegekukorica hozamait, ahol a termésnövekedés meghaladta a szignifikáns határt. A varianciaanalízis megbízhatósága igen erős, a számított $R^{2}$ érték 0,973 .

A következő vizsgált csoport a két takarmány kukorica hibrid volt, melyek termésátlagait nyomon követtük a vizsgálat során.

\section{3. ábra: A P9903 hibrid termésátlagának alakulása szalagos csepegtető} öntözéses kísérletben 2016. (Szarvas)

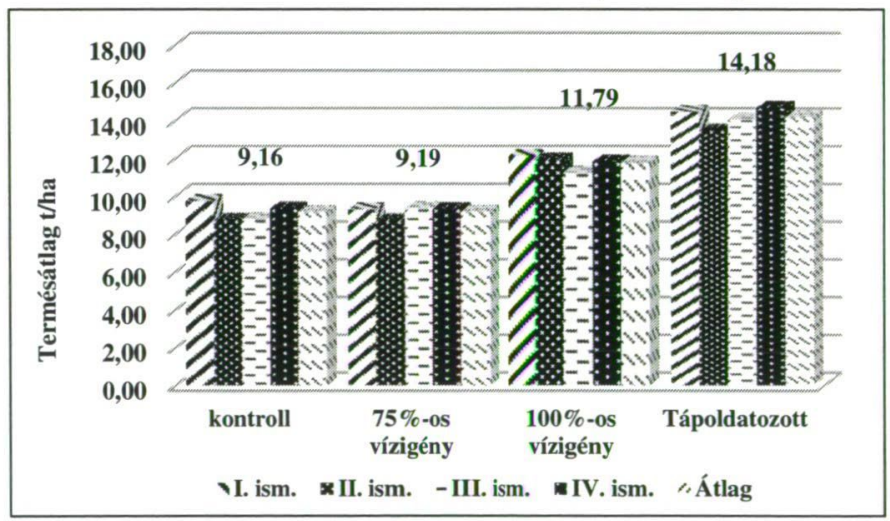

Forrás: A szerző saját szerkesztése. (2016.) 


\section{4. ábra: A P9903 hibrid termésátlagának alakulása szalagos csepegtető öntözéses kísérletben 2017. (Szarvas)}

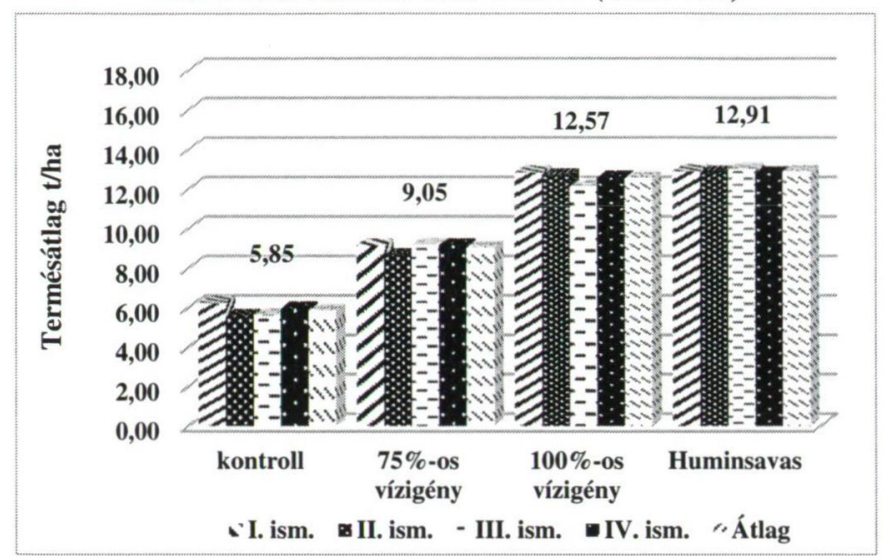

Forrás: A szerző saját szerkesztése. (2017.)

\section{5. ábra: A DKC4541 hibrid termésátlagának alakulása szalagos csepegtető öntözéses kísérletben 2016. (Szarvas)}

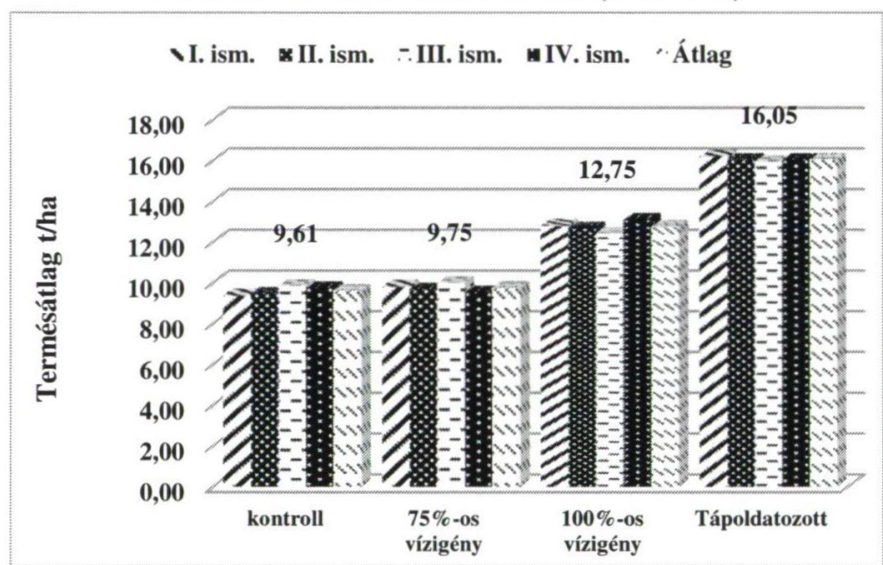

Forrás: A szerző saját szerkesztése. (2016.)

A takarmánykukorica hozamok vizsgálata hasonló eredményt mutatott 2016ban, mint a csemegekukorica hibridé. A növény öntözés nélküli hozamai, valamint a 75\%-os vízigényt kielégítő öntözési hozamok közt ebben a vizsgált évben nem alakult ki különbség. Ennek oka a megfelelő mennyiségủ és eloszlású csapadék volt. A növény teljes vízigényét azonban a természetes módon lehullott csapadék még ebben a kedvező évben sem tudta fedezni, ami azzal járt, hogy a teljes 100\%-os vízigény kielégítésével a kukorica hozamai növelhetőek voltak 2016-ban is. A hozamok 22,3-24,5\%-kal növekedtek a kontroll parcellák hozamaihoz képest. (lásd: 3. és 5. ábra) 


\section{6. ábra: A DKC4541 hibrid termésátlagának alakulása szalagos csepegtető öntözéses kísérletben 2017. (Szarvas)}

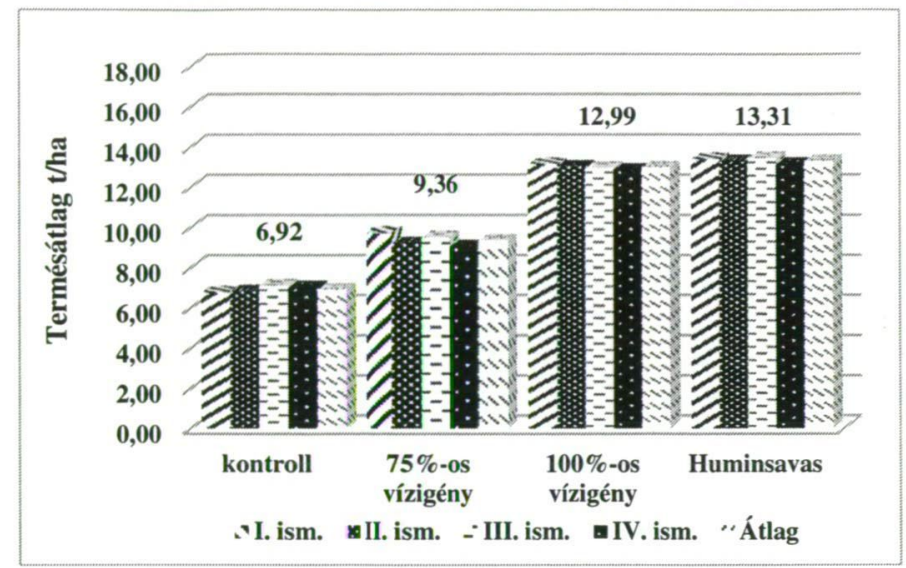

Forrás: A szerző saját szerkesztése. (2017.)

2017-ben a csapadékellátottság sokkal kedvezőtlenebb volt, a tenyészidőben lehullott csapadék nem érte el a 30 éves átlagértékeket sem. Ezért a termésátlagok jelentősen elmaradtak az előző év eredményeihez képest. (lásd: 4. és 6. ábra)

A legnagyobb terméscsökkenés az előző évekhez képest a kontroll öntözés nélküli parcellákon következett be. Ez leginkább a kukorica vízellátás szempontjából legérzékenyebb időszakában (július, augusztus) bekövetkező csapadékszegény periódusnak köszönhető. A növény vízigényének $75 \%$-os kielégítését biztosító öntözéssel a hozamok már igen erősen növekedtek, mindkét vizsgált hibrid esetében meghaladták a 9 t/ha-os értéket (9,05 és 9,36 t/ha).

Amennyiben a növény vízigényét 100\%-ban kielégítettük az öntözés során, akkor kialakultak a hibridekre jellemző 12-13 tonna közötti hozamok. Az öntözés hatására kialakuló kedvező vízellátás a hibridek esetében megmutatja, hogy a klímaváltozás hatására egyre gyakoribb száraz periódusok terméscsökkentő hatása jelenős, a kísérletünkben a kontroll rossz vízellátású parcellákon a hozamok 6,72 t/ha-ral (P9903) valamint 6,07 t/ha-ral (DKC4541) csökkentek.

2016-ban a tápoldatozott parcellák ezt tovább tudták fokozni, aminek az oka elsősorban az a kedvező növény-élettani helyzet, hogy a növény a kijuttatott vízzel azonnal oldott formájú tápanyaghoz jut a gyökér hajszáleres felszívó zónájában. Ez is rámutat arra a fontos tényre, hogy optimális tápanyagellátás csak megfelelő mennyiségü, és a növény számára elérhető formájú víz jelenlétében lehetséges. A tápoldatozott parcellák átlagtermése 14,18-16,05 t/ha közt változtak, amely terméstöbblet már elérte a gazdaságosság és a jövedelmezőség határát a kísérlet eredményei alapján.

2017-ben a hagyományos tápoldat helyett egy huminsavas kezelést teszteltünk, szalagos csepegtető öntözéssel kijuttatva. A kezelések eredményeként hasonlóan a 2016-os évhez további termésátlag növekedést tudtunk mérni. A hozamnövekedés nagysága 2017-ben 340 kg/ha (P9903 hibrid) és 320 kg/ha (DKC4541 hibrid) volt. 
4. táblázat: A kukorica termésátlagának variancia táblázata 2016.

\begin{tabular}{|l|c|c|c|c|c|}
\hline & SQ & df & MS & F & Sig. \\
\hline Corrected Model & $177,909^{\mathrm{a}}$ & 3 & 59,303 & 130,696 &, 000 \\
Intercept & 2227,447 & 1 & 2227,447 & 4908,988 &, 000 \\
Öntözés & 43,080 & 2 & 21,540 & 47,471 & $\mathbf{, 0 0 0}$ \\
Tápoldat & 32,405 & 1 & 32,405 & 71,415 & $\mathbf{, 0 0 0}$ \\
Error & 12,705 & 28 &, 454 & & \\
Total & 4467,583 & 32 & & & \\
Corrected Total & 190,614 & 31 & & & \\
\hline
\end{tabular}

a. R Squared $=, 933$ (Adjusted R Squared $=, 926$ )

A 2016-os terméseredmények statisztikai elemzése során azt tapasztaltuk, hogy a csemegekukoricához hasonlóan az árukukorica hibridek is szignifikáns termésátlag növekedést értek el, mind az öntözés, mind pedig a tápoldat kezelés hatására. Mivel a szalagos csepegtető öntözéssel a tápoldat kijuttatása külön befektetés nélkül is könnyedén megvalósítható, kiemelkedő jelentőséggel bír a további szignifikáns termésátlag növekedés.

5. táblázat: A kukorica termésátlagának variancia táblázata 2017.

\begin{tabular}{|l|c|c|c|c|c|}
\hline & SQ & df & MS & F & Sig. \\
\hline Corrected Model & $244,093^{\mathrm{a}}$ & 3 & 81,364 & 516,665 &, 000 \\
Intercept & 1481,352 & 1 & 1481,352 & 9406,608 &, 000 \\
Öntözés & 164,140 & 2 & 82,070 & 521,145 & $\mathbf{, 0 0 0}$ \\
Tápoldat &, 436 & 1 &, 436 & 2,766 & $\mathbf{, 1 0 7}$ \\
Error & 4,409 & 28 &, 157 & & \\
Total & 3689,476 & 32 & & & \\
Corrected Total & 248,502 & 31 & & & \\
\hline
\end{tabular}

a. $R$ Squared $=, 982$

A 2017-es eredmények statisztikai kiértékelésekor is a termésátlagok variancia analízisét végeztük el elsöként. Az eredmények alapján az öntözés ebben az évben is szignifikáns termésátlag növekedéssel járt, de a huminsavas kezelés termésnövekménye nem érte el a statisztikailag is igazolható különbséget, a hozamnövekedés nem volt szignifikáns.

A vizsgálat során a varianciaanalízisen kívül elvégeztük a tényezök korreláció és regresszió analízisét is. A Pearson korreláció vizsgálat során azt tapasztaltuk, hogy az öntözés szoros pozitív hatással volt a terméseredmények alakulására 2016. évben. 
6. táblázat: A kukorica termésátlaga és az öntözés közötti korreláció vizsgálata 2016.

\begin{tabular}{|cl|l|l|}
\hline & Öntözés & Termésátlag \\
\hline Öntözés & Pearson Correlation & 1 &, $795^{* *}$ \\
& Sig. (2-tailed) & & 000 \\
$\mathrm{~N}$ & 32 & 32 \\
\hline Termes & Pearson Correlation & $\mathbf{7 9 5}$ & 1 \\
& Sig. (2-tailed) & 000 & \\
$\mathrm{~N}$ & 32 & 32 \\
\hline
\end{tabular}

A vizsgálat eredménye az, hogy a termésátlag és az öntözés között szoros pozitív korreláció áll fenn. A vizsgálat nagyon alacsony, 0,01-os szinten adott szignifikánsan megbízható eredményt.

2017-ben is elvégeztuik a korreláció vizsgálatot, aminek eredményeként látható, hogy a száraz évjáratban az öntözési kezelésnek köszönhetően még szorosabb pozitív korreláció áll fenn. (lásd: 7. táblázat)

7. táblázat: A kukorica termésátlaga és az öntözés közötti korreláció vizsgálata 2017.

\begin{tabular}{|ll|l|l|}
\hline & & Termés & Öntözés \\
\hline Termés & Pearson Correlation & 1 &, $9^{* *}$ \\
& Sig. (2-tailed) & &, 000 \\
& $\mathrm{~N}$ & 32 & 32 \\
\hline Öntözés & Pearson Correlation & $\mathbf{9 8 8}$ & 1 \\
& Sig. (2-tailed) &, 000 & \\
& $\mathrm{~N}$ & 32 & 32 \\
\hline
\end{tabular}

**. Correlation is significant at the 0.01 level (2-tailed). 
8. táblázat: A kukorica termésátlaga és az tápoldat kezelés közötti korreláció vizsgálata 2016.

\begin{tabular}{|ll|l|l|}
\hline & & Tápoldat & Termésátlag \\
\hline Tápoldat & Pearson Correlation & 1 &, $\mathbf{8 4 1}$ \\
& Sig. (2-tailed) & &, 000 \\
$\mathrm{~N}$ & 32 & 32 \\
\hline Termésátlag & Pearson Correlation & $\mathbf{8 4 1}$ & 1 \\
& Sig. (2-tailed) &, 000 & \\
$\mathrm{~N}$ & 32 & 32 \\
\hline
\end{tabular}

**. Correlation is significant at the 0.01 level (2-tailed).

A tápoldat kezelés még szorosabb összefüggést mutatott, a korrelációs együttható értéke 0,841 , ami szoros pozitív összefüggést mutat.

Mivel 2017-ben nem volt igazolható szignifikáns termésnövekedés az alkalmazott huminsavas kezelésnek köszönhetően, ezért az eredmények korreláció vizsgálatát nem végeztük el a szigifikancia hiánya miatt.

7. ábra: Az öntözés lineáris regresszió diagramja 2016. (Szarvas)

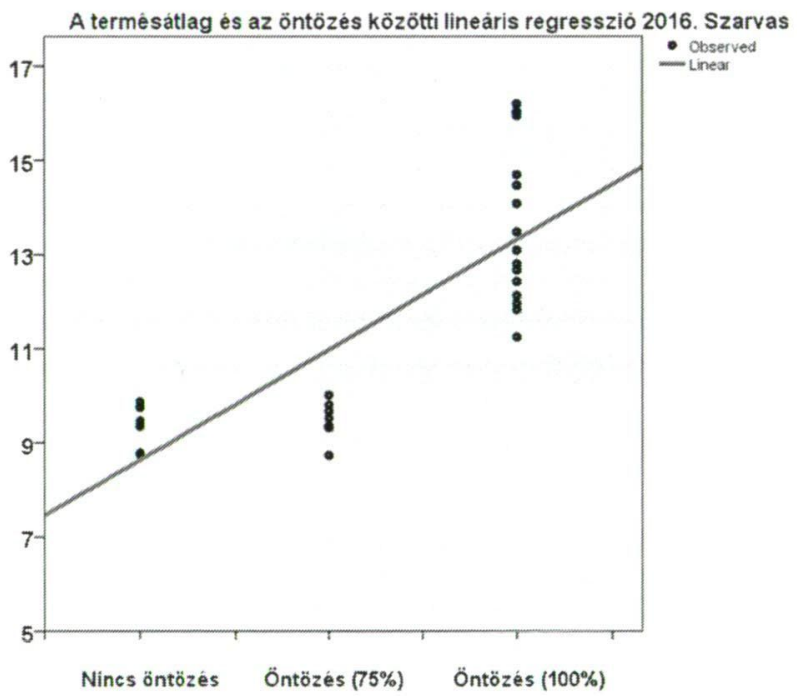

Forrás: A szerző saját szerkesztése. (2016.) 


\section{8. ábra: Az öntözés lineáris regresszió diagramja 2017. (Szarvas)}

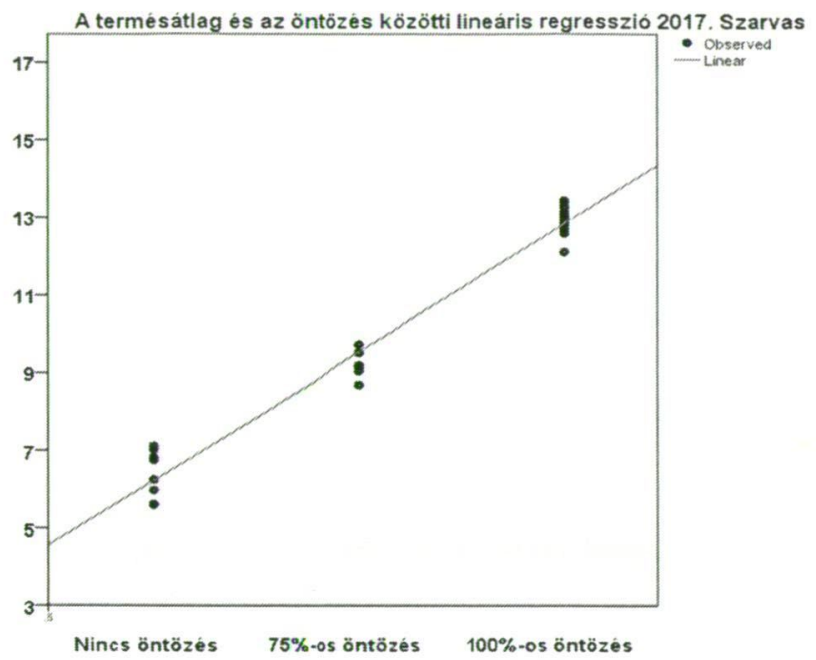

Forrás: A szerző saját szerkesztése. (2017.)

\section{Következtetések, összegzés, záró megjegyzések, záró gondolatok}

Mindösszesen megállapítható volt az, hogy a kukorica csepegtető szalagos öntözése egy igen alacsony vízfelhasználású, energiatakarékos és hatékony öntözési technológia, amely a kukorica öntözésének kiemelkedő hazai technikai újítása lehet a jövőben az intenzív gazdálkodást folytató termelők számára.

A kukorica termésátlaga jelentősen növelhető, ha javítjuk a növény vízellátását. Sok területen csak kevés víz áll rendelkezésre az öntözéshez. Kísérletünkben csepegtető öntözés hatását vizsgáltuk a kukorica termésátlagára 2016 és 2017 évben. A hozamok 2016-ban 22,3-24,5\%-kal növekedtek a kontroll parcellák hozamaihoz képest, míg ez a hozamnövekedés a szárazabb 2017-es évben elérte a 46,73-53,46\%ot. Kísérletünkben a termésátlag növekedése már ökonómiailag is gazdaságos volt.

\section{Köszönetnyilvánítás}

A publikáció az EFOP-3.6.1-16-2016-00016 „SZIE Szarvasi Campusának kutatási és képzési profiljának specializálása intelligens szakosodással: mezőgazdasági vízgazdálkodás, hidrokultúrás növénytermesztés, alternatív szántóföldi növénytermesztés, ehhez kapcsolódó precíziós gépkezelés fejlesztése.” címủ projekt támogatásával jött létre.

\section{Irodalomjegyzék}

Antal J. (Szerk.) (2005): Növénytermesztéstan 1. Mezőgazda Kiadó, Budapest.

Bocz E. (1992): Szántóföldi növénytermesztés. Mezőgazda Kiadó, Budapest.

Csajbók J. (2004): A növénytermesztési tér vízgazdálkodása. Mezőgazdasági vízgazdálkodási szakirányú továbbképzés jegyzet. 
Pepó P. , Sárvári M. (2011): Gabonanövények termesztése. Az Agrármérnöki MSc szak tananyagfejlesztése. TÁMOP-4.1.2-08/1/A-2009-0010 projekt. <http://www.tankonyvtar.hu/hu/tartalom/tamop425/0010_1A_Book_09_Gabonanovenyek_ter mesztese/index.html>

Ruzsányi, L. (1981): Öntözés. In: Növénytermesztési praktikum, Mezőgazdasági Kiadó, Budapest.

Szalóki, S. (1989): A növények vízigénye, vízhasznosítása és öntözővíz-szükséglete. In: Szalai Gy. (szerk.): Az öntözés gyakorlati kézikönyve. Mezögazdasági Kiadó, Budapest. 